\title{
FAKTOR-FAKTOR YANG MEMPENGARUHI KECENDERUNGAN PENERIMAAN UNQUALIFIED OPINION WITH MODIFIED PARAGRAPHGOING CONCERN
}

\author{
Yunita', Deasy Ariyanti Rahayuningsih ${ }^{2}$ \\ Universitas Trisakti \\ XiePhingYun@yahoo.com, deasy@stietrisakti.ac.id
}

\begin{tabular}{l|l}
\hline Keyword & Abstract \\
\hline $\begin{array}{l}\text { Audit Quality, Company's Financial } \\
\text { Condition, Prior Audit Opinion, }\end{array}$ & $\begin{array}{l}\text { The purpose of this study is to investigate empirically the relationship } \\
\text { between audit quality, company's financial condition, prior audit opinion, } \\
\text { company's growth, company's size, and debt default that influence the }\end{array}$ \\
$\begin{array}{l}\text { Size, Debt Default and Unqualified } \\
\text { Opinion With Modified Paragraph } \\
\text { Going Concern }\end{array}$ & $\begin{array}{l}\text { going concern. Data to be used is secondary data and were taken from } \\
\text { Indonesia Stock Exchange official website. The research used } 42 \text { non- } \\
\text { financial companies as sample by using purposive sampling method. } \\
\text { This study used logistic regression to test the hypothesis. Data for this } \\
\text { study comprises from the financial statement of non-financial companies } \\
\text { in Indonesia over four year period of 2008-20II. The research finding } \\
\text { can be summarized as follows. The result showed that the prior audit } \\
\text { opinion has significant influence over unqualified opinion with modified } \\
\text { paragraph going concern. On the other hand, audit quality, company's } \\
\text { financial condition, company's growth, company's size, and debt default } \\
\text { don't have influence on unqualified opinion with modified paragraph } \\
\text { going concern. }\end{array}$
\end{tabular}

(C2016 JMB, All right reserved

\section{PENDAHULUAN}

Banyaknya pihak yang menggunakan laporan keuangan sebagai bahan pertimbangan untuk pengambilan keputusan sehingga adanya pengungkapan mengenai masalah kelangsungan hidup akan sangat berguna bagi pihak-pihak berkepentingan. Jika masalah mengenai kelangsungan hidup tidak diungkapkan, pengguna laporan keuangan akan sangat dirugikan jika auditee mengalami gulung tikar yang sama sekali tidak dapat diprediksi karena tidak adanya pengungkapan mengenai masalah kelangsungan hidup perusahaan. Selain itu, auditor juga akan mengalami kerusakan reputasi dan juga dapat dituntut oleh pengguna laporan keuangan karena tidak adanya pengungkapan mengenai kelangsungan hidup perusahaan.

Motivasi melakukan penelitian ini adalah untuk membantu perusahaan, investor maupun setiap pihak yang menggunakan laporan keuangan agar dapat mengidentifikasi penyebab perusahaan menerima opini unqualified opinion with modified paragraph going concern. Penelitian ini merupakan replikasi penelitian Santosa dan Wedari (2007). Alasan peneliti melakukan replikasi penelitian adalah karena opini audit unqualified opinion with modified paragraph going concern merupakan masalah yang penting untuk dipertimbangkan oleh investor dalam melakukan investasi di pasar modal.

Penelitian ini diharapkan dapat memberikan manfaat untuk: investor, sebagai bahan pertimbangan dalam menetapkan keputusan investasi. Bagi peneliti, penelitianini untuk menambah pengetahuan peneliti dalam bidang auditing agar lebih memahami faktorfaktor yang mempengaruhi kecenderungan penerimaan unqualified opinion with modified paragraph going concern. Selanjutnya untuk penelitian yang akan datang, hasil penelitian ini diharapkan dapat menambah pengetahuan 
pembaca dan peneliti selanjutnya, juga dapat menjadi bahan referensi untuk penelitian selanjutnya.

\section{TINJAUAN PUSTAKA}

\section{Agency Theory}

Yuliana (2009) menggambarkan teori agensi sebagai teori yang berbicara mengenai perbedaan kepentingan prinsipal dan agen yang berpengaruh terhadap penyediaan informasi, kinerja, dan insentif. Karena itu, dibutuhkan pihak ketiga yang independen sebagai mediator yang berfungsi untuk menjembatani kepentingan antara prinsipal dan agen.

\section{Kualitas Audit dengan Kecenderungan Penerimaan Unqualified Opinion with Modified Paragraph Going Concern}

Auditor yang memiliki kualitas audit yang lebih baik cenderung akan mengeluarkan opini going concern apabila klien mempunyai masalah mengenai kelangsungan hidupnya (Santosa dan Wedari 2007). Auditor skala besar dapat menyediakan kualitas audit yang lebih baik dari pada auditor skalakecil, termasuk dalam pengungkapan masalah going concern (Santosa dan Wedari 2007). Selain itu, auditor skala besar akan memiliki kualitas yang lebih tinggi karena memiliki karakteristik yang dapat dikaitkan dengan kualitas seperti pelatihan, pengakuan internasional, serta adanya peer review (Craswell et al. (1995) dalam Fanny dan Saputra (2005)). Hasil penelitian Wijaya et al. (2009) dan Rahayu (2007) menunjukkan bahwa kualitas audit berpengaruh terhadap kecenderungan penerimaan unqualified opinion with modified paragraph going concern Sedangkan hasil penelitian Amilin dan Indrawan (2008), Susanto (2009), Santosa dan Wedari (2007), Setyarno et al. (2006) dan Herusetya (2008) menunjukkan hal yang sebaliknya.

$\mathrm{Ha}_{1}$ : Kualitas audit berpengaruh terhadap kecenderungan penerimaan unqualified opinion with modified paragraph going concern.

\section{Kondisi Keuangan Perusahaan dengan Kecenderungan Penerimaan Unqualified Opinion with Modified Paragraph Going Concern}

Tingkat kesehatan perusahaan dapat dilihat dari kondisi keuangan suatu perusahaan.
Salah satu media yang dapat kita pakai untuk menilai kondisi keuangan perusahaan adalah laporan keuangan perusahaan. Menurut Susanto (2009), auditor hanya akan memberikan opini audit going concern jika perusahaan mengalami kesulitan melanjutkan kelangsungan usahanya. Penelitian Susanto (2009), Rudyawan dan Badera (2009) dan Setyarno et al. (2006) menunjukkan bahwa kondisi keuangan perusahaan berpengaruh terhadap kecenderungan penerimaan unqualified opinion with modified paragraph going concern sedangan penelitian Santosa dan Wedari (2007) menunjukkan hal yang sebaliknya.

$\mathrm{Ha}_{2}$ : Kondisi keuangan perusahaan berpengaruh terhadap kecenderungan penerimaan unqualified opinion with modified paragraph going concern.

\section{Opini Audit Tahun Sebelumnya dengan Kecenderungan Penerimaan Unqualified Opinion with Modified Paragraph Going Concern}

Opini going concern tahun sebelumnya akan menjadi pertimbangan penting bagi auditor untuk menentukan opini going concern di tahun selanjutnya. Jika auditor memberikan opini audit going concern pada tahun sebelumnya, maka kemungkinan besar auditor akan memberikan opini going concern pada tahun selanjutnya. Penelitian Setyarno et al. (2006), Santosa dan Wedari (2007), Januarti dan Fitrianasari (2008), Susanto (2009) dan Dewayanto (201I) menunjukkan bahwa opini audit tahun sebelumnya berpengaruh terhadap kecenderungan penerimaan unqualified opinion with modified paragraph going concern.

$\mathrm{Ha}_{3}$ : Opini audit tahun sebelumnya berpengaruh terhadap kecenderungan penerimaan unqualified opinion with modified paragraph going concern.

\section{Pertumbuhan Perusahaan dengan Kecenderungan Penerimaan Unqualified Opinion with Modified Paragraph Going Concern}

Pertumbuhan perusahaan mengindikasikan kemampuan perusahaan dalam mempertahankan kelangsungan hidupnya (Rudyawan dan Badera 2009). Pertumbuhan penjualan akan memberi peluang bagi auditee untuk meningkatkan laba dan mempertahankan kelangsungan hidupnya. Penelitian Santosa dan Wedari (2007), Kumalawati (20I2), Rudyawan 
dan Badera (2009) menunjukkan bahwa pertumbuhan perusahaan tidak berpengaruh terhadap penerimaan unqualified opinion with modified paragraph going concern.

$\mathrm{Ha}_{4}$ : Pertumbuhan perusahaan berpengaruh terhadap kecenderungan penerimaan unqualified opinion with modified paragraph going concern.

\section{Ukuran Perusahaan dengan Kecenderungan Penerimaan Unqualified Opinion with Modified Paragraph Going Concern}

Mutcher (1985) dalam Santosa dan Wedari (2007) menyatakan bahwa auditor lebih sering mengeluarkan opini audit going concern pada perusahaan kecil karena auditor mempercayai bahwa perusahaan besar mampu menyelesaikan kesulitan-kesulitan keuangan yang dihadapinya daripada perusahaan kecil. Penelitian Santosa dan Wedari (2007) menunjukkan bahwa ukuran perusahaan berpengaruh terhadap kecenderungan penerimaan unqualified opinion with modified paragraph going concern sedangkan penelitian Januarti dan Fitrianasari (2008) dan Dewayanto (20II) menunjukkan hal yang sebaliknya.

$\begin{aligned} \mathrm{Ha}_{5} \text { : } & \text { Ukuran perusahaan berpengaruh } \\ & \text { terhadap kecenderungan penerimaan } \\ & \text { unqualified opinion with modified } \\ & \text { paragraph going concern }\end{aligned}$

\section{Debt Default dengan Kecenderungan penerimaan Unqualified Opinion with Modified Paragraph Going Concern}

Debt default didefinisikan sebagai kegagalan debitor (perusahaan) untuk membayar hutang pokok dan atau bunganya pada waktu jatuh tempo (Chen dan Church 1992 dalam Praptorini dan Januarti 2007). Kegagalan dalam memenuhi kewajiban hutang dan atau bunga merupakan indikator going concern yang banyak digunakan auditor dalam menilai kelangsungan hidup perusahaan (Susanto 2009). Penelitian Praptitorini dan Januarti (2007) menunjukkan bahwa debt default berpengaruh terhadap kecenderungan penerimaan unqualified opinion with modified paragraph going concern sedangkan penelitian Susanto (2009) menunjukkan hal yang sebaliknya.

Ha6: Debt default berpengaruh terhadap kecenderungan penerimaan unqualified opinion with modified paragraph going concern.

\section{METODE PENELITIAN}

\section{Jenis Penelitian}

Jenis penelitian ini adalah kausalitas. Penelitian kausalitas adalah penelitian yang dilakukan untuk mengidentifikasi hubungan sebab akibat antar variabel (Zikmund et al. 20l0, 57). Obyek dalam penelitian ini adalah laporan keuangan dan laporan auditor independen seluruh perusahaan non-keuangan yang terdaftar di Bursa Efek Indonesia pada tahun 2008 sampai tahun 20II.

\section{Sampel dan Teknik Pengambilan Data}

Pengambilan sampel diperoleh dengan metode purposive sampling, yang bertujuan untuk mendapatkan sampel sesuai dengan kriteria yang ditentukan. Kriteria-kriteria pemilihan sampel dalam penelitian ini adalah (I) perusahaan nonkeuangan yang konsisten terdaftar di Bursa Efek Indonesia pada tahun 2008-20I I; (2) Perusahaan non-keuangan yang laporan keuangannya menggunakan satuan mata uang rupiah selama periode penelitian; (3) Perusahaan nonkeuangan yang mengalami kerugian minimal dua periode laporan keuangan selama periode penelitian; (4) Perusahaan non-keuangan yang datanya tersedia selama periode penelitian.

\section{Operasional Variabel}

Variabel Dependen

Pengukuran terhadap Unqualified Opinion withexplanatory paragraph going concerndilakukan dengan menggunakan skala nominal dan diukur dengan variabel dummy, yaitu perusahaan nonkeuangan yang menerima Unqualified Opinion withexplanatory paragraph going concernatas laporan keuangannya diberi nilai “I”, sedangkan perusahaan yang menerima opini selain Unqualified Opinion withexplanatory paragraph going concern akan diberi nilai " 0 ".

\section{Variabel Independen}

Kualitas audit merupakan kualitas atas jasa yang diberikan oleh auditor kepada kliennya (Susanto 2009). Kualitas audit diproksikan dengan skala auditor (Santosa dan Wedari 2007). Auditor skala besar adalah KAP big four, sedangkan Auditor skala kecil adalah KAP nonbig four. Pengukuran kualitas audit menggunakan skala nominal dan diukur dengan variabel dummy, yaitu skor "I" untuk KAP skala besar (big four) dan skor "0" untuk KAP skala kecil (non-big four). 
Kondisi keuangan perusahaan menggambarkan tingkat kesehatan perusahaan yang sesungguhnya (Ramadhany 2004 dalam Setyarno et al. 2006). Variabel kondisi keuangan perusahaan diukur dengan skala rasio dan dihitung dengan menggunakan salah satu model prediksi kebangkrutan, yaitu Revised Altman Model (1993).Revised Altman Model adalah sebagai berikut:

$$
Z=\underset{Z}{Z}=\underset{Z_{5}}{0,7 \mid 7 Z_{1}+0,847 Z_{2}+3,107 Z_{3}+0,420 Z_{4}+0,998}
$$

Dimana:

$Z_{1}=$ Working Capital / Total Assets

$Z_{2}=$ Retained earnings / Total Assets

$Z_{3}=$ Earnings before interest and taxes / Total assets

$Z_{4}=$ Book value of equity / Book value of debt

$Z_{5}=$ Sales $/$ Total Assets

Opini Audit Tahun Sebelumnya didefinisikan sebagai opini audit yang diterima pada tahun sebelumnya. Pengukuran variabel opini audit tahun sebelumya menggunakan skala nominal, dan juga menggunakan variabel dummy, yaitu unqualified opinion with modified paragraph going concernakan diberi skor "I", sedangkanopini selain unqualified opinion with explanatory paragraph going concernakan mendapat skor "0".

Pertumbuhan perusahaan merupakan tingkat perubahan penjualan setiap tahunnya. Skala pengukuran yang digunakan dalam variabel pertumbuhan perusahaan adalah skala rasio. Perhitungan variabel pertumbuhan perusahaan dapat dirumuskan sebagai berikut:

Pertumbuhan perusahaan $=$ Penjualan bersih ${ }_{\mathrm{t}}-{\text { Penjualan } \text { bersih }_{\mathrm{t}-1}}$

Keterangan: Penjualan bersiht-1

Penjualan bersih $_{\mathrm{t}}=$ Penjualan bersih tahun berjalan.

Penjualan bersih $_{t-1}=$ Penjualan bersih tahun sebelumnya.

Ukuran perusahaan adalah variabel yang mengukur seberapa besar atau kecilnya perusahaan sampel (Santosa dan Wedari 2007). Pengukuran variabel ini menggunakan skala rasio, dengan menggunakan natural logaritma dari total aktiva.

Debt default didefinisikan sebagai kegagalan debitor (perusahaan) untuk membayar hutang pokok dan atau bunganya pada waktu jatuh tempo (Chen dan Church 1992 dalam Praptitorini dan Januarti 2007). Variabel debt default diukur dengan menggunakan skala nominal. Variabel debt default diukur dengan menggunakan variabel dummy $(I=$ status variabel debt default, $0=$ tidak debt default) (Praptitorini dan Januarti 2007).

\section{HASIL PENELITIAN DAN PEMBAHASAN}

\section{Uji Normalitas}

Hasil pengujian normalitas menggunakan One Sample Kolmogorov-Smirnov menunjukkan bahwa variabel kualitas audit, kondisi keuangan perusahaan, opini audit tahun sebelumnya, pertumbuhan perusahaan, ukuran perusahaan dan debt default memiliki asymp.Sig $<0,05$ sehingga data tidak terdistribusi dengan normal.

\section{Tabel I. Uji Kolmogorov-Smirnov}

\begin{tabular}{|l|c|l|}
\hline Nama Variabel & Asymp.Sig & \multicolumn{1}{|c|}{ Keterangan } \\
\hline Kualitas audit & 0,000 & $\begin{array}{l}\text { Data terdistribusi } \\
\text { tidak normal }\end{array}$ \\
\hline $\begin{array}{l}\text { Kondisi keuangan } \\
\text { perusahaan }\end{array}$ & 0,000 & $\begin{array}{l}\text { Data } \\
\text { terdistribusitidak } \\
\text { normal }\end{array}$ \\
\hline $\begin{array}{l}\text { Opini audit tahun } \\
\text { sebelumnya }\end{array}$ & 0,000 & $\begin{array}{l}\text { Data terdistribusi } \\
\text { tidak normal }\end{array}$ \\
\hline $\begin{array}{l}\text { Pertumbuhan } \\
\text { perusahaan }\end{array}$ & 0,000 & $\begin{array}{l}\text { Data terdistribusi } \\
\text { tidak normal }\end{array}$ \\
\hline $\begin{array}{l}\text { Ukuran } \\
\text { perusahaan }\end{array}$ & 0,007 & $\begin{array}{l}\text { Data terdistribusi } \\
\text { tidak normal }\end{array}$ \\
\hline Debt default & 0,000 & $\begin{array}{l}\text { Data terdistribusi } \\
\text { tidak normal }\end{array}$ \\
\hline
\end{tabular}

\section{Uji Hipotesis}

\section{Hasil Uji Model Fit}

Uji model fit digunakan untuk menilai apakah model yang dihipotesakan menggambarkan data input. Menguji overall model fit menggunakan nilai -2 log likelihood. Hasil penelitian menunjukkan bahwa nilai-2 log likelihood mengalami penurunan (lihat tabel 2). Penurunan nilai -2 log likelihood menunjukkan model regresi yang baik atau menunjukkan bahwa model yang dihipotesiskan fit dengan data.

\section{Tabel 2. Overall Model Fit}

\begin{tabular}{|l|l|}
\hline & -2 Log likelihood \\
\hline Block 0: Beginning Block & 222,285 \\
\hline Block I: Method = Enter & 134,526 \\
\hline
\end{tabular}

\section{Hasil Uji Nagelkerke's R Square}

Uji Nagelkerke's $R$ square digunakan untuk melihat seberapa besar variabel dependen dapat dijelaskan oleh variabel independen. Tabel 3 menunjukkan bahwa variabel dependen yang 
dapat dijelaskan oleh variabel independen adalah sebesar $55,5 \%$. Sedangkan sisanya sebesar $44,5 \%$ dapat dijelaskan oleh variabel lain yang tidak terdapat dalam model.

Tabel 3. Nilai Nagelkerke's $R$ square

\begin{tabular}{|c|l|l|l|}
\hline Step & \multicolumn{2}{|l|}{$\begin{array}{l}\text { likelihood Log } \\
\text { Square }\end{array}$} & \multicolumn{2}{|l|}{$\begin{array}{l}\text { Nagelkerke R } \\
\text { Square }\end{array}$} \\
\hline I & I34,526(a) &, 407 &, 555 \\
\hline
\end{tabular}

\section{Hasil Uji Hosmer and Lemeshow's Goodness of Fit Test}

Uji Hosmer and Lemeshow's goodness of fit digunakan untuk menguji apakah model fit dengan data observasi penelitian. Model dapat dikatakan fit dengan data observasi apabila nilai Sig.Hosmer and Lemeshow test> 0,05. Hasil pengujian Hosmer dan Lemeshow goodness of fit test menunjukkan nilai sig >0,05 (lihat tabel 4) sehingga model dapatdikatakan fit dengan data observasi.
Tabel 4. Hosmer and Lemeshow Test

\begin{tabular}{|c|c|c|c|}
\hline Step & Chi-square & $\mathrm{df}$ & Sig. \\
\hline$I$ & 5,247 & 8 & ,731 \\
\hline
\end{tabular}

\section{Hasil Uji Ketepatan Prediksi}

Berdasarkan tabel 5, dapat disimpulkan bahwa ada 63 perusahaan yang menerima unqualified opinion with modified paragraph going concern, tetapi yang tepat diprediksi berdasarkan model adalah sebanyak 48 perusahaan atau sebesar $76,2 \%$, dan sisanya 15 perusahaan $(23,8 \%)$ tidak tepat diprediksi yang merupakan kesalahan tipe I. Perusahaan yang tidak menerima opini unqualified opinion with modified paragraph going concern adalah 105 perusahaan, tetapi yang tepat diprediksi oleh model adalah 96 perusahaan (9I,4\%), sisanya yaitu sebanyak 9 perusahaan $(8,6 \%)$ tidak tepat diprediksi yang merupakan kesalahan tipe II. Secara keseluruhan ketepatan prediksi berdasarkan model sebesar I 44 perusahaan $(96+48)$ atau $85,7 \%$.

Tabel 5. Classification Table

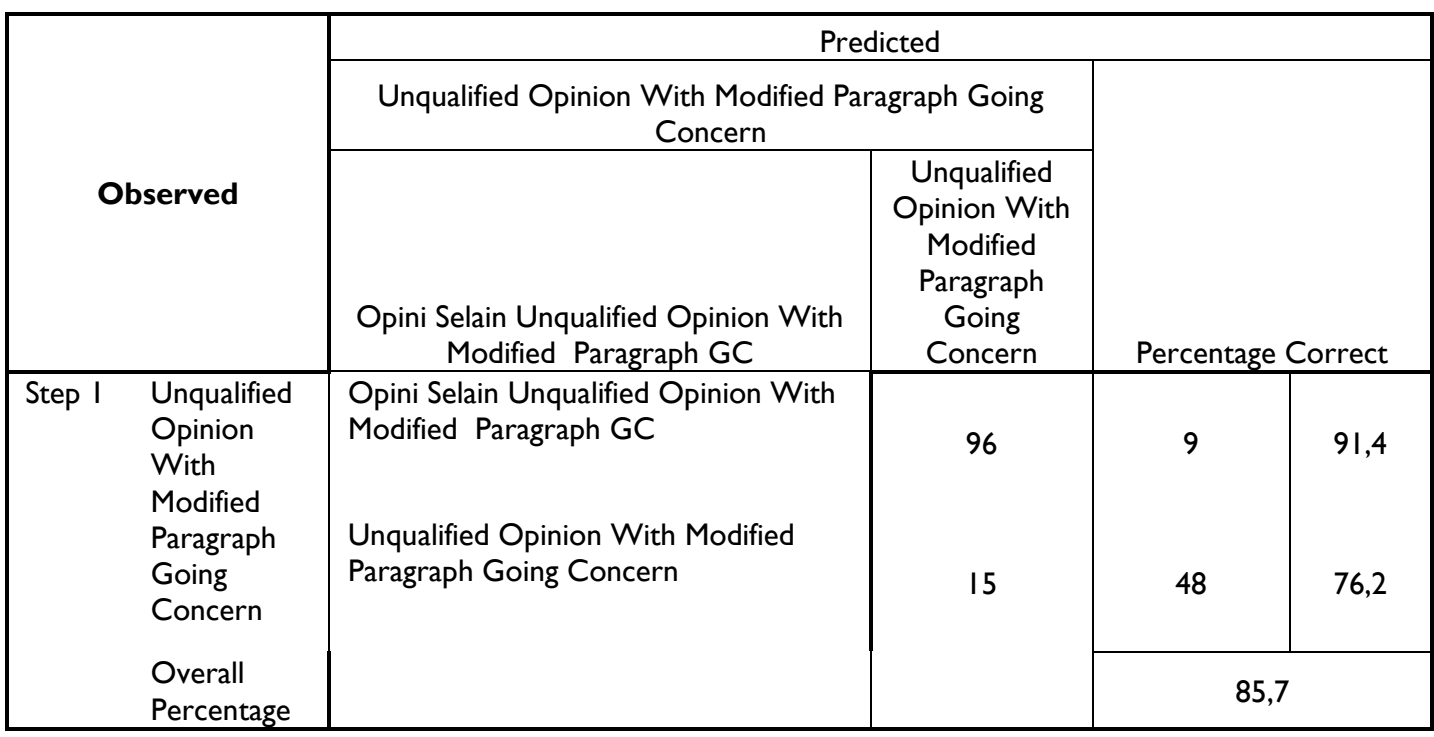

\section{Hasil Pengujian Hipotesis}

Berdasarkan variables in the equation pada tabel 6, diperoleh persamaan regresi logistik, yaitu:

Ln $\frac{\mathrm{GC}}{1-\mathrm{GC}}=0,748-0,709 \mathrm{~K} \_\mathrm{AU}-0,005 \mathrm{Z} \_\mathrm{SCR}+3,580$ PRIOP + 0,000 GRWTH- 0,093 SZ - 0,182 D_DEF+ $\varepsilon$

- Variabel kualitas audit (K_AU) menunjukkansignifikansi $0,3 \mathrm{I} 3>0,05$ yang berarti $\mathrm{Ha}$ । gagal diterima.
- Variabel kondisi keuangan perusahaan (Z_SCR) menunjukkan tingkat signifikansi $0,786>0,05$ yang berarti $\mathrm{Ha}_{2}$ gagal diterima.

- Variabel opini audit tahun sebelumnya (PRIOP) menunjuk kantingkat signifikansi $0,000<0,05$ yang berarti $\mathrm{Ha}_{3}$ diterima.

- Variabel pertumbuhan perusahaan (GRWTH) menunjukkan tingkat signifikansi $0,833>0,05$ yang berarti $\mathrm{Ha}_{4}$ gagal diterima.

- Variabel ukuran perusahaan menunjukkan tingkat signifikansi 0,396 >0,05 yang berarti $\mathrm{Ha}_{5}$ gagal diterima. 
- Variabel debt default (D_DEF) menunjukkan tingkat signifikansi $0,80 \overline{3}>0,05$ yang berarti

$\mathrm{Ha}_{6}$ gagal diterima.

Tabel 6. Variables in the Equation

\begin{tabular}{|cc|c|c|c|c|c|c|}
\hline & & B & S.E. & Wald & df & Sig. & $\operatorname{Exp}($ B) \\
\hline Step I(a) & K_AU &,- 709 &, 702 & $\mathrm{I}, 020$ & $\mathrm{I}$ &, 313 &, 492 \\
& Z_SCR &,- 005 &, 017 &, 074 & $\mathrm{I}$ &, 786 &, 995 \\
& PRIOP & 3,580 &, 472 & 57,414 & $\mathrm{I}$ &, 000 & 35,872 \\
& GRWTH &, 000 &, 000 &, 044 & $\mathrm{I}$ &, 833 & $\mathrm{I}, 000$ \\
& SZ &,- 093 &, $\mathrm{I} 10$ &, 722 & $\mathrm{I}$ &, 396 &, 911 \\
& D_DEF &,- 182 &, 727 &, 063 & $\mathrm{I}$ &, 803 &, 834 \\
& Constant &, 748 & 2,884 &, 067 & $\mathrm{I}$ &, 795 & 2,113 \\
\hline
\end{tabular}

\section{PENUTUP}

\section{Kesimpulan}

I. Kualitas audit tidak berpengaruh secara signifikan terhadap penerimaan unqualified opinion with modified paragraph going concern. Hasil penelitian ini konsisten dengan penelitian Amilin dan Indrawan (2008), penelitian Susanto (2009), penelitian Santosa dan Wedari (2007), penelitian Setyarno et al. (2006), dan penelitian yang dilakukan oleh Herusetya (2008), tetapi tidak konsisten dengan penelitian Wijaya et al. (2009) danpenelitian Rahayu (2007).

2. Kondisi keuangan perusahaan tidak berpengaruh secara signifikan terhadap penerimaan unqualified opinion with modified paragraph going concern. Hasil penelitian ini konsisten dengan penelitian Santosa dan Wedari (2007) tetapi tidak konsisten dengan penelitian yang dilakukan oleh Susanto (2009), penelitan Rudyawan dan Badera (2009), penelitian Dewayanto (20II) juga penelitian Setyarno et al. (2006).

3. Opini audit tahun sebelumnya berpengaruh secara signifikan terhadap penerimaan unqualified opinion with modified paragraph going concern. Hasil penelitian ini konsisten dengan penelitian yang dilakukan oleh Setyarno et al. (2006), penelitian Santosa dan Wedari (2007), penelitian Januarti dan Fitrianasari (2008), penelitian Dewayanto (20I I), juga penelitian Susanto (2009).

4. Pertumbuhan perusahaan tidak berpengaruh secara signifikan terhadap penerimaan unqualified opinion with modified paragraph going concern. Hasil penelitian ini konsisten dengan penelitian yang telah dilakukan oleh Santosa dan Wedari (2007), penelitian Kumalawati (20I2), juga penelitian Rudyawan dan Badera (2009).

5. Ukuran perusahaan tidak berpengaruh secara signifikan terhadap penerimaan unqualified opinion with modified paragraph going concern. Hasil penelitian ini konsisten dengan penelitian yang telah dilakukan oleh Januarti dan Fitrianasari (2008) dan penelitian Dewayanto (20II) tetapi tidak konsisten dengan penelitian yang telah dikakukan oleh Santosa dan Wedari (2007).

6. Debt default tidak berpengaruh secara signifikan terhadap penerimaan unqualified opinion with modified paragraph going concern. Hasil penelitian ini konsisten dengan penelitian yang telah dilakukan oleh Susanto (2009) tetapi tidak konsisten dengan penelitian yang telah dilakukan oleh Praptitorini dan Januarti (2007).

\section{Saran}

Penelitian selanjutnya dapat mengikutsertakan perusahaan keuangan dalam sampel penelitian, menambahkan variabelvariabel lain yang belum dimasukkan dalam penelitian ini seperti opinion shopping, dan memperpanjang periode penelitian.

\section{DAFTAR PUSTAKA}

Amilin dan Ady Indrawan. 2008. Analisis Penilaian Going Concern Perusahaan dan Opini Audit Oleh KAP Big Four Dengan KAP Non Big Four (Studi pada Emiten di Bursa 
Efek Indonesia). Jurnal Ekonomi, September, Vol. XVIII, No. 2, hlm. 72-83.

Deloitte Touche Tohmatsu Limited. 2013.

"About Us". http://www.deloitte.com

/view/en_ID/id/about-us/index.htm. DiaksesTanggal 24 April 2013.

Dewayanto, Totok. 20II. Analisis FaktorFaktor yang Mempengaruhi Penerimaan Opini Audit Going Concern pada Perusahaan Manufaktur yang Terdaftar di Bursa Efek Indonesia. Fokus Ekonomi, I Juni, Vol. 6, No. I, hlm.8I-I04.

Djufri. 20II. Memahami Opini Audit Going Concern Dalam Rangka Investasi Di Pasar Modal. Aktiva, Oktober, Vol. 4, No. 7, hlm. 83-97.

Fanny, Margaretta dan Sylvia Saputra. 2005. Opini Audit Going Concern: Kajian Berdasarkan Model Prediksi Kebangkrutan, pertumbuhan Perusahaan, dan Reputasi Kantor Akuntan Publik (Studi Pada Emiten Bursa Efek Jakarta). Simposium Nasional Akuntansi VIII, Solo, I5-16 September, hlm. 966-978.

Ghozali, Imam. 20II. Aplikasi Analisis Multivariate Dengan Program IBM SPSS 19. Semarang: Badan Penerbit Universitas Diponegoro.

Haron, Hasnahet al. 2009. Factors Influencing Auditors' Going Concern Opinion. Asian Academy of Management Journal, January, Vol. 14, No. I, hlm. I-19.

Herusetya, Antonius. 2008. Kaitan Firm Size Kantor Akuntan Publik (KAP) Terhadap Mutu Laporan Audit Going Concern: Studi di Indonesia. Integrity - Jurnal Akuntansi dan Keuangan, April, Vol. 2, No. I, hlm. 363366.

Institut Akuntan Publik Indonesia (IAPI). 20II. Standar Profesional Akuntan Publik Per 3I Maret. Jakarta: Salemba Empat. 2013. "Jakarta". http://www.iapi.or.id/iapi/download/Directory 2013

IJakarta.pdf. Diaksestanggal 24 April 2013.

Januarti, Indira dan Ella Fitrianasari. 2008. Analisis Rasio Keuangan dan Rasio Non Keuangan yang Mempengaruhi Auditor dalam Memberikan Opini Audit Going Concern pada Auditee (Studi Empiris pada Perusahaan Manufaktur yang Terdaftar di BEJ
Tahun 2000-2005). Jurnal Maksi, Januari, Vol. 8, No. I, hlm. 43-58.

KPMG. 2013.2 "About". http://www.kpmg.com/id/en/about/Pages/def ault.aspx. Diaksestanggal 24 April 2013.

Kumalawati, Lely. 20I2. Faktor-Faktor yang Mempengaruhi Opini Going Concern: Studi Empiris pada Perusahaan Manufaktur yang Terdaftar di Bursa Efek Indonesia. Jurnal Akuntansi dan Ekonomi Bisnis, Vol. I, No. I, hlm. I-30.

Praptitorini, Mirna Dyah dan Indira Januarti. 2007. Analisis Pengaruh Kualitas Audit, Debt Default dan Opinion Shopping Terhadap Penerimaan Opini Going Concern. Simposium Nasional Akuntansi X, Unhas Makassar, 26-28 Juli, hlm. I-25.

Pricewaterhouse Coopers International Limited. 2013. “About Us". http://www.pwc.com/id/en/aboutus/index.jhtml. Diaksestanggal 24 April 2013.

Priyatno, Dwi. 2008. Mandiri Belajar SPSS (Statistical Product and Service Solution) untuk Analisis Data dan Uji Statistik. Yogyakarta: MediaKom.

Rahayu, Puji. 2007. Assessing Going Concern Opinion: A Study Based on Financial and Non-Financial Informations (Empirical Evidence of Indonesian Banking Firms Listed on JSX and SSX). Simposium Nasional Akuntansi X, Unhas Makassar, 26-28 Juli, hlm. I-32.

Rudyawan, Arry Pratama dan I Dewa Nyoman Badera. 2009. Opini Audit Going Concern: Kajian Berdasarkan Model Prediksi Kebangkrutan, Pertumbuhan Perusahaan, Leverage, dan Reputasi Auditor. AUDI - Jurnal Akuntansi dan Bisnis, Juli, Vol. 4, No. 2, hlm. 129-I38.

Santosa, Arga Fajar dan Linda Kusumaning Wedari. 2007. Analisis Faktor Faktor yang Mempengaruhi Kecenderungan Penerimaan Opini Audit Going Concern. Jurnal Akuntansi dan Auditing Indonesia, Desember, Vol. II, No. 2, hlm. I4I-I58.

Santosa, Purbayu Budi dan Muliawan Hamdani. 2007. Statistika Deskriptif dalam Bidang Ekonomi dan Niaga. Semarang: Penerbit Erlangga. 
Setyarno, Eko Budi, Indira Januarti dan Faisal. 2006. Pengaruh Kualitas Audit, Kondisi Keuangan Perusahaan, Opini Audit Tahun Sebelumnya, Pertumbuhan Perusahaan Terhadap Opini Audit Going Concern. Simposium Nasional Akuntansi IX, Padang, 23-26 Agustus, hlm. I-25.

Sugiyono. 2012. Metode Penelitian Kuantitatif Kualitatif dan R\&D. Bandung: Alfabeta.

Susanto, Yulius Kurnia. 2009. Faktor-Faktor yang Mempengaruhi Penerimaan Opini Audit Going Concern Pada Perusahaan Publik Sektor Manufaktur. Jurnal Bisnis dan Akuntansi, Desember, Vol. II, No. 3, hlm. I55-I73.

Wijaya, Okie Indra, Yasmin Umar Assegaf dan Rahmawati. 2009. Pengaruh Kualitas Audit dan Proxy Going Concern Terhadap Opini Audit Going Concern Pada Perusahaan Non regulasi di Bursa Efek Indonesia (BEI). Jurnal Akuntansi dan Manajemen, Desember, Vol. 20, No. 3, hlm. I4I-I 56.

Yuliana, Christina. 2009. Kajian Pustaka Terhadap Teori Agensi dan Akuntansi Manajemen. Jurnal Akuntansi dan Manajemen, April, Vol. 20, No. I, hlm. 6I-68.

Zikmund, William G., Barry J. Babin, Jon C. Carr and Mitch Griffin. 20I0. Business Research Method. South-Western: Cengage Learning. 